\title{
Air Cargo Shipments And Regional Employment: The Northern Nevada Case
}

Bahram Adrangi, (Email: adrangi@up.edu), University of Portland

Richard D. Gritta, (Email: gritta@up.edu), University of Portland

Kambiz Raffiee, (Email: raffiee@unr.edu), University of Nevada, Reno

\begin{abstract}
Air cargo is a critical component for developing an integrated transportation system to facilitate regional economic diversification and growth. Additionally, demand for air cargo shipments is affected by regional, national and international economic conditions. To get a better sense on these issues in Northern Nevada, a study was conducted to determine : (1) characteristics of business behavior for air cargo and other freight modes at Reno-Tahoe International Airport and (2) if employment in Reno MSA, as a proxy for regional business activities, has a systematic impact on air cargo shipments at Reno-Tahoe International Airport. The first question is examined by conducting interviews and surveys of the firms in Northern Nevada in 2002-2003. The second question is evaluated by estimating time-series models using monthly data on employmen in Reno MSA and air cargo shipments at Reno-Tahoe International Airport. The findings do support the importance of regional economic factors in determining the demand for air cargo shipments. JEL Codes: L93, L9 and DOO
\end{abstract}

\section{INTRODUCTION}

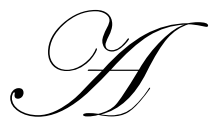

ccording to Air Transport World, the international freight-ton kilometers posted a 5.3 percent increase in 2003, improved from a 5 percent increase in 2002 over 2001. The role of air cargo to trade growth has shown a substantial increase in the last decade as a result of intense globalization. "The air cargo volume throughout the world has grown at between 1.5 and 2 times the rate of worldwide GDP growth. Average annual growth in freight-tone kilometers on international scheduled services during the last decade is 7.9 percent. Future air cargo growth is expected to be robust. According to Boeing World air Cargo Forecast 2000-2001, world airborne cargo will grow by 6.4 percent per year for the next twenty years.” (Zhang, 2003). The significant growth in air cargo has boosted both international trade and regional economic growth and diversification.

Research in economics of air cargo has focused mainly on logistical issues in developing infrastructure for domestic and international air-cargo hub, policy issues in air cargo liberalization and investigation of non-linear patterns in air cargo for forecasting purposes. Zhang (2003) provides an analysis of the benefits from developing of an international airfreight hub and examines its application to Hong Kong to become a major air cargo hub in the highly competitive air cargo industry in China and East Asia. Zhang, Van Hui and Leung (2004) develop an oligopoly model to examine the effect of an air cargo alliance on competition in passenger markets. They show that an air cargo alliance between passenger airlines will likely increase the airlines' own output, while simultaneously decreasing their rivals' power in both passenger and air cargo markets. Additionally, Zhang and Zhang (2002) develop a multi-market oligopoly model to examine the effect of air cargo liberalization on competition between all-cargo carriers and mixed passenger/cargo (combi) carriers. Adrangi, Chatrath and Raffiee (2001) applied the chaos theory to investigate the presence of nonlinear structures in the U.S. airfreight and airmail. They find nonlinearities in both series evidenced by a generalized autoregressive conditional heteroscedastic $(\mathrm{GARCH})$ model that performs superior to those of autoregressive models.

On the other hand, few studies have attempted to analyze the role of air cargo in regional economic development. Radnotti (2002) discusses the overall role of an integrated air cargo transportation in promoting cost 
efficiency and delivery of goods and materials.

This paper examines the effect of air cargo on regional economic development by examining the relationship between the air cargo shipments at Reno-Tahoe International Airport (RTIA) and employment in Reno MSA in Northern Nevada. The next section provides a description of the region of the study, the RTIA, and the summary of two studies examining the characteristics of air cargo demand by firms in Northern Nevada. Section III presents the methodology used. The data is presented in Section IV. The empirical results are the subject of Section V. Section VI closes with a summary and conclusions of the study.

\section{BACKGROUND INFORMATION}

The Northern Nevada is one of the fastest growing regions in the country fueled by a steady economic diversification. The largest county of Northern Nevada is Washoe with a total population of 373,233 as of July 1, 2003, an increase of 3.2 percent over the same period in 2002 (Nevada Department of Taxation and Nevada State Demographer). The two major cities of Northern are Reno and Sparks with a respective population of 195,727 and 78,435 as of July 1,2003 , an increase of 4.2 percent over the same period in 2002 (Nevada Department of Taxation and Nevada State Demographer). The state of Nevada has a total population of over 2.2 million as of July 1, 2003, an increase of 4.1 percent over the same period in 2002 (Nevada Department of Taxation and Nevada State Demographer). Reno is about 230 miles from the Bay area in California. The capital of the state is Carson City, located 25 miles south of Reno.

The Reno-Tahoe International Airport is the major commercial airport in Northern Nevada and is totally selfsufficient financially. In January 2004, it offered 89 daily nonstop departures to 17 cities with approximately 10,596 available seats. This compares with 74 daily departures to 16 cities and 8,455 available seats in January 2003 . It is important to note that 2003 was the best year for total passengers at the RTIA since 1997, with a year-end total of over 4.5 million passengers showing an increase of 1.68 percent over 2002. This signals a healthy recovery by the RTIA from Reno Air stopping its operations at RTIA in December 1998 when it was acquired by American Airlines and the terrorist attacks of September 11, 2001. Southwest Airlines is the largest airline at the RTIA with a market share of over 51 percent in 2003.

In January 2004, a total of over 8.6 million pounds of cargo moved through the RTIA which was an increase of 1.16 percent from January 2003. In 2003, total volume of air cargo at RTIA (freight and mail) was over 103.9 million pounds, a decrease of 2.3 percent over 2002. Airmail shipments at RTIA were over 4 million pounds in 2003, a decrease of 15.8 percent versus 2002. This is a sharp rebound in airmail shipments where there was a significant decline of 59 percent in airmail in 2002 versus 2001 at RTIA as well as at other airports in the West Coast, i.e., Los Angeles had a decline of 48 percent in 2002 and Portland International had a decline of 63 percent in 2002 (Source: World Air Cargo Daily). In 2003, over 99 million pounds of airfreight (excluding airmail) were moved through RTIA, a decline of 1.67 percent versus 2002. Federal Express is the largest air cargo carrier at the RTIA with a nearly 50 percent of market share, followed by UPS with a 29 percent market share.

In an attempt to better understand the current of future needs of the business community of Northern Nevada related to air cargo, Phase I of a study was developed by the Bureau of Business and Economic Research of the College of Business Administration of the University of Nevada, Reno in cooperation with Reno-Tahoe International Airport in January 2002 (Ryan, Raffiee and Bartholet, June 2002). The study consisted of developing an air cargo interview instrument that was used to conduct in-depth interviews of a select group of major companies, representing a variety of industries, to determine they key characteristics of their air cargo needs some of the current and future needs of the business community related to air cargo. The interview instrument was developed through an interactive process between the Bureau of Business and Economic Research and Reno-Tahoe International Airport. After several iterations, the instrument was pre-tested, and then additional modifications were made.

The Nevada Department of Employment Training and Rehabilitation (DETR) database was used to identify the top fifty firms by number of employees in manufacturing, wholesale trade and retail. From these lists, the following firms were identified and contacted the following firms: International Gaming Technology, the world's 
largest slot machines manufacture, Tyco Valves and Controls in manufacturing, Arrow Electronics, a major worldwide distributor of electronic devices, Microflex Medical, a distributor of surgical and medical gloves, Summit Racing Equipment, a retailer in outdoor and recreational equipment, and Patagonia, a retailer in clothing.

Specifically, the goal of the study was to obtain a basic understanding of the following:

- Which aspects of freight routing decisions were most important,

- Who typically made the freight routing decisions,

- What information was tracked by the firms,

- $\quad$ Origins and destinations of air freight,

- How local air cargo services could be improved,

- $\quad$ Projected growth of air cargo related to projected firm growth, and

- $\quad$ The nature of the responding businesses.

The major findings of Phase I of Northern Nevada air cargo study are:

- $\quad$ Most firms don't track freight shipments by mode of transportation,

- Most firms select a carrier, and determine the delivery time required,

- Ability to track the shipments, reliability/ consistency, and damage/lost shipment incidence are more important than cost,

- $\quad$ Cost remains a very important factor,

- For international connections,

- businesses bypass RTIA for the primary air cargo needs,

- Direct connections desired,

$\circ \quad$ Every additional handling increases the risk of damage, delays, or lost shipments, therefore, local businesses use LAX, SFO or other airports in the region and connect to Northern Nevada by motor transport, and

- With future international connections through RTIA, this could change.

- $\quad$ RTIA's current role for local firms' air cargo:

- Regional connections (direct non-stop),

$\circ \quad$ Special shipments (samples, returns, rush orders), and

$\circ \quad$ Air cargo carriers (FedEx, UPS).

- $\quad$ Lack of sufficient air cargo lift may restrict local economic development for certain firms:

$\circ \quad$ Cut-off times too early,

$\circ \quad$ Limitations for handling palletized shipments, and

- Need for more direct connections.

- $\quad$ A cross-dock facility may be needed (third party developer),

- $\quad$ A focused educational outreach should be developed by RTIA targeting key businesses and shippers, and

- As the economy in the Reno MSA continues to add employment in manufacturing, wholesale/distribution and retail sectors, the air cargo volume through RTIA will continue to grow.

To expand the scope of work in Phase I of Northern Nevada air cargo study, the Bureau of Business and Economic Research of the College of Business Administration of the University of Nevada, Reno in cooperation with Reno-Tahoe International Airport conducted a Phase II of the study in the Fall 2002 (Ryan, Raffiee and Bartholet, March 2003). A web-based interview instrument was developed that was sent to over 1,900 local firms in Northern Nevada using the membership lists, with email addresses, from the key economic development authorities including Carson City Chamber of Commerce, Carson Valley Chamber of Commerce, Reno-Sparks Chamber of Commerce, Sparks Chambers of Commerce, Economic Development Authority of Western Nevada and Northern Nevada Development Authority. One hundred and twenty two firms completed the survey, a 6.38 percent response rate, and approximately an additional 50 firms indicated that the survey wasn't applicable to them. 
The respondents represented the following industries (five of respondents picked two categories): mining, construction, manufacturing, transportation, communications \& public utilities, trade, finance, insurance \& real Estate, services, government and other.

The major findings of Phase II of Northern Nevada air cargo study are:

- $\quad$ Overall, the respondents were evenly split regarding how the freight decision is made:

- $\quad 51$ percent first select the mode of transportation, and

○ $\quad 5.1$ percent first select the carrier and let the carrier select the mode of transportation.

- $\quad$ Imbalance of Inbound \& Outbound freight:

$\circ \quad$ For those who track volume by number of shipments, both the mean and median indicate outbound volume is greater than inbound,

- $\quad$ For those who track number of parcels, results were similar, and

- These results verify RTIA reporting.

- $\quad$ Primary air cargo carriers:

- 23.6 percent of firms use FedEx,

- 22.5 percent use UPS,

- 19.5 percent use USPS,

○ $\quad 10.0$ percent use Airborne Express, and

- Other trail down from there in the single digits.

- $\quad$ Predicting air freight volume:

- Respondents predicted business growth in 2003,

- Mean prediction was 38.7 percent growth,

$\circ \quad$ Median prediction was 11 percent growth, and

0 Air freight growth was predicted to be about the same as firm growth rate.

- $\quad$ Customs and Immigration Facilities:

○ $\quad 54.1$ percent of firms were aware of the facilities,

- 7.4 percent of the firms utilize the facilities,

- $\quad 13.6$ percent of the firms that were aware of the facilities use the facilities, and

$0 \quad$ Manufacturing firms had the lowest awareness (44.4 percent) and the highest utilization (25 percent of those aware use the facilities).

The findings of Phases I and II of Northern Nevada air cargo study have resulted into a campaign by RenoTahoe International Airport to inform the businesses of Northern Nevada to be aware of the air cargo facilities and services that it offers.

\section{METHODOLOGY}

This investigation employs a number of complementary statistical tools. The initial investigation starts with estimating several exploratory regression models. The objective of these regression models is to provide evidence on the lead-lag relationship between employment and cargo variables in the sample of the study. To this end, the dynamic lead-lag relationship between employment and total cargo is examined by estimating Equation (1).

$$
\text { Employment }_{t}=\alpha_{1}+\theta_{i} \sum_{-j}^{j} C G_{t-i}+\text { error }_{t}
$$

Equation (1) includes both the lead and lagged values of cargo shipments. The objective is to examine the statistical significance of lead and lagged cargo values. For example, if the lagging values of CG are statistically significant, then cargo shipments are leading employment. On the other hand, statistically significant leading CG variables would indicate that employment may be leading cargo shipment activities.

Equations (2) through (4) examine whether expected or unexpected components of cargo shipments at RenoTahoe International Airport are determinant by employment changes in Reno MSA. For example, Equation (2) breaks 
cargo shipments into its two components while Equation (4) expresses employment as a function of expected cargo shipments.

$$
\begin{aligned}
& \text { Employment }_{t}=\alpha_{1}+\beta_{i} \Sigma U X C G_{t-1}+\theta_{i} \Sigma X C G_{t-i}+\text { error }_{t} \\
& \text { Employment }_{t}=\alpha_{1}+\beta_{i} \Sigma U X C G_{t-1}+\text { error }_{t} \\
& \text { Employment }_{t}=\alpha_{1}+\theta_{i} \Sigma X C G_{t-i}+\text { error }
\end{aligned}
$$

In Equations (2) through (4) UXCG and XCG are unexpected and expected components of cargo shipment. Other variations of the above regressions may be estimated to complete the preliminary analysis.

To derive the expected and unexpected components of cargo shipments we employ two commonly used statistical approaches. The first method involves the use of Hodrick-Prescott (HP) filter, suggested by Hodrick and Prescott (1980). This filter decomposes a series, x, into its trend and unexpected deviations from the trend. The second method requires finding the appropriate ARIMA models. The objective is to use the white noise residuals of the ARIMA model and treat them as the unexpected component of the series under question. The objective of this step is to verify the robustness of the statistical results derived from the HP Filter.

Only the results of HP will be reported in the interest of brevity. However, the results from ARIMA models are qualitatively identical to those obtained using HP filter. The HP filter requires minimizing

$$
\sum_{t=0}^{T}\left(x_{t}-\bar{x}_{t}\right)^{2}+\theta \sum_{t=0}^{T-1}\left[\left(\bar{x}_{t+1}-\bar{x}_{t}\right)-\left(\bar{x}_{t}-\bar{x}_{t-1}\right)\right], \text { for } \theta>0
$$

The technique allows for a stochastic trend component while deriving the temporary or unexpected component. ${ }^{1}$ Under the assumption that RTIA authorities form rational expectations regarding cargo shipments trend, the off-trend or temporary portion of the series may be considered the unexpected volume of shipment. The objective is to determine which component of cargo shipments are sector employment have been correlated in the past.

For instance, if the expected component of cargo shipments is correlated with sector employment, then we may conclude that there is a long-run effect on sector employment as employment rises in anticipation of future increase in economic activity. However, if the employment series in various sectors are correlated with the unexpected component of cargo shipments, the findings may suggest that there are temporary rises in employment which respond to temporary and unexpected changes in the cargo volume. Therefore, this type of employment rise may be temporary and not persistent over a meaningful period of time.

The second econometric tool used in this paper is the vector autoregressive technique (VAR). A VAR consists of a system of dynamic simultaneous Equations. In each Equation, an endogenous variable is a function of exogenous as well as the lagged values of all endogenous variables. Thus, a VAR allows for the simultaneous and dynamic interaction of all endogenous variables. More importantly, a VAR provides an unrestricted approximation to the reduced form of an unknown structural system of simultaneous Equations. Though the underlying structure is not specified, it is assumed to exist.

Zellner and Palm (1974), Zellner (1979), and Palm (1983) show that any linear structural model can be written in the form of a vector autoregressive moving average multivariate time series model (VARMA) whose coefficients are combinations of the structural coefficients. These researchers show that under mild regularity conditions a VARMA model can be written as a VAR model. Therefore, a VAR model serves as a flexible approximation to the reduced form of any wide variety of simultaneous structural models. To paraphrase, the reduced forms of traditional simultaneous models are special cases of VAR models.

The consensus among researchers is that VAR models are dynamic and capture the simultaneous interactions among all variables. They are suitable to describe the economic data-generation process. VAR models are typically 
smaller than structural models and therefore require less data. In addition they do not use economic theory in their specification. The procedure used in this paper is as follows. We use VAR models in conjunction with the Akaike's Information Criterion (AIC) and Schwarz Information Criterion (SIC) to determine the dimensionality of Equations of the system.

A VAR model serves as a flexible approximation to the reduced form of any wide variety of simultaneous structural models. This system of Equations can be written in compact matrix notation as follows:

$$
\left[\begin{array}{ll}
1-\alpha_{11}(L) & -\alpha_{12}(L) \\
-\alpha_{21}(L) & 1-\alpha_{22}(L)
\end{array}\right]\left[\begin{array}{l}
C G_{t} \\
E M P_{t}
\end{array}\right]+\left[\begin{array}{l}
\beta_{1} \\
\beta_{2}
\end{array}\right]=\left[\begin{array}{l}
u_{1 t} \\
u_{2 t}
\end{array}\right]
$$

where $\alpha_{11}(L)$ through $\alpha_{22}(L)$ are n-th order scalar polynomials in the lag operator $\mathrm{L}$, where $\alpha_{i j}(L)=\sum_{k=1}^{m} a_{i j} L^{k}$, and $L^{k} \mathrm{x}_{t}=\mathrm{x}_{t-k}$, and $\mathrm{m}$ is the lag length specified. Variables $\mathrm{PRF}_{t}$ and $\mathrm{CAP}{ }_{t}$ represent profits and capacity (available seat miles), respectively, $\beta_{i}$, model constants, and $u_{t}=\left[u_{1 t} u_{2 t}\right]$ is a vector of white noise residuals process. $^{2}$

A final consideration in using the VAR model is the choice of the order of the process, p. Without a formal method, the selection of lag order in a VAR model will be arbitrary and could lead to specification error (See Fair and Schiller (1990), and Funke (1990)). Several criteria, similar to those used in the distributed lag models, are suggested to determine the model dimension (see Judge, et al. (1985) and Lutkepohl (1985)). In this paper, the minimum Akaike (1974) Information Criteria (AIC) determines the optimum lag length (see Judge, et al. (1988)). It can be shown that the GLS estimators of the coefficients are identical to the OLS estimators under the above assumption regarding the residuals.

VAR models are routinely used to perform impulse response analysis, which allow us to measure the various period impact of the $u_{t-i}$ on each variable. Impulse response analysis requires a vector moving average (VMA) representation of a VAR. The VMA allows us to trace out the time path of the various shocks on the variables of the VAR system. Consider the VMA process given by

$$
\left[\begin{array}{l}
C G_{t} \\
E M P_{t}
\end{array}\right]=\left[\begin{array}{l}
C \bar{G} \\
E \bar{M} P
\end{array}\right]+\left[\begin{array}{ll}
\phi_{11}(i) & \phi_{12}(i) \\
\phi_{21}(i) & \phi_{22}(i)
\end{array}\right]\left[\begin{array}{l}
\varepsilon_{C G t-i} \\
\varepsilon_{E M P t-i}
\end{array}\right] .
$$

The sets of coefficients $\phi_{k j}(i)$ are called the impulse response functions. For example $\phi_{12}(0)$ is the instantaneous impact of a one-unit change in $\varepsilon_{C A P t}$ on PRF ${ }_{t}$. Similarly, $\phi_{12}(1)$ is the one period response of $\mathrm{PRF}_{t}$ to one unit change in $\varepsilon_{C A P t-1}$. The accumulated effect of unit impulses in $\varepsilon_{C A P t}$ on PRF for example, can be computed by summing the coefficients of the impulse response function. Thus, the effect of $\varepsilon_{C A P t}$ on the PRF ${ }_{t}$ after $\mathrm{n}$ periods is given by

$\sum_{i=0}^{n} \phi_{12}(i)$

To produce reliable VAR estimates and impulse response analysis, variables of the model are required to be stationary, i.e., not have unit roots. 


\section{Unit Root Tests}

The ADF (Dickey and Fuller (1979)) and PP (Phillips and Perron (1988)) tests of unit roots are used in the present study. The ADF entails estimating $\Delta \mathrm{x}_{t}=\alpha+\beta \mathrm{x}_{t-1}+\sum_{j=1}^{L} \gamma_{j} \Delta \mathrm{x}_{t-j}+u_{t}$ and testing the null hypothesis that $\beta=0$ versus the alternative of $\beta<0$, for any $x$. The lag length $\mathrm{j}$ in the ADF test regressions are determined by the Akaike Information Criterion (AIC). The PP test estimates $\Delta \mathrm{x}_{t}=\alpha+\beta \mathrm{x}_{t-1}+u_{t}$ and tests the null hypothesis that

$\beta=0$ versus the alternative of $\beta<0$. Three variations of the ADF and PP regressions are estimated: with intercept, trend and intercept, and neither trend nor intercept. The purpose of this approach is to insure that the test results are robust in the presence of drifts and trends. The PP test may be more appropriate if autocorrelation in the series under investigation is suspected. The statistics are transformed to remove the effects of autocorrelation from the asymptotic distribution of the test statistic. The formula for the transformed test statistic is given in Perron (1988). The lag truncation of the Bartlett Kernel in the PP test is determined by Newey and West (1987). In both the ADF and PP tests the MacKinnon (1990) critical values are used. Accepting the null hypothesis means that the series under consideration is not stationary and a unit root is present.

\section{Cointegration Tests And Long-Run Equilibrium}

We also test for the long-run equilibrium relationship among the variables employing Johansen and Juselius (1990) cointegration test. Cointegration refers to the possibility that non-stationary variables may have a linear combination that is stationary. Such a linear combination, the cointegrating vector, implies that there is a long-run equilibrium relationship among variables, i.e., variables will not wander off apart from one another over extended periods of time. Therefore, cointegration between the stock index, price levels, and interest rates implies a long-run relationship between these variables. The test of cointegration employed in this paper, Johansen (1988) and Johansen and Juselius (1990) methodology, is a multivariate generalization of the methodology suggested by Engle and Granger (1987). A brief description of the test is as follows. Let

$\Delta \mathrm{x}_{t}=\sum_{i=1}^{p-1} \Gamma_{i} \Delta x_{t-i}+\pi \mathrm{x}_{t-1}+\varepsilon_{t}$,

where $\mathrm{x}_{t}$ and $\varepsilon_{t}$ are $\left(\mathrm{n}_{*} 1\right)$ vectors and $\pi$ is an $\left(\mathrm{n}_{*} \mathrm{n}\right)$ matrix of parameters. The Johansen (1988) methodology requires estimating the system of Equations in (9) and examining the rank of matrix $\pi$. If rank $(\pi)=0$, then there is no stationary linear combination of the $\left\{\mathrm{x}_{i t}\right\}$ process, the variables are not cointegrated. Since the rank of a matrix is the number of non-zero eigenvalues $(\lambda)$, the number of $\lambda>0$ represents the number of cointegrating vectors among the variables. The test for the non-zero eigenvalues is normally conducted using the following two test statistics:

$\lambda_{\text {trace }}(\mathrm{r})=-\mathrm{T} \sum_{i=r+1}^{n} \ln \left(1-\hat{\lambda}_{i}\right)$

$\lambda_{\max }(\mathrm{r}, \mathrm{r}+1)=-\mathrm{T} \ln \left(1-\hat{\lambda}_{r+1}\right)$

where $\hat{\lambda}_{i}$ is the estimated eigenvalues, and $\mathrm{T}$ is the number of valid observations. Note that $\lambda_{\text {trace }}$ statistic is simply

the sum of $\lambda_{\max }$ statistic. In Equation (13), $\lambda_{\text {trace }}$ tests the null hypothesis that the number of distinct cointegrating vectors is less than or equal to $r$ against a general alternative. $\lambda_{\text {max }}$ statistic tests the null hypothesis of $r$ cointegrating vectors against $\mathrm{r}+1$ cointegrating vectors. Johansen and Juselius (1990) and Osterwal- Lenum (1992) derive the critical values of $\lambda_{\text {trace }}$ and $\lambda_{\text {max }}$ by simulation method. 


\section{DATA}

As was explained earlier, our hypothesis is that the demand for air cargo is a derived demand caused by regional economic conditions affected by diversification efforts. Local employment data is used as a proxy for economic activity. Before presenting the empirical results on the relationship between air cargo shipments at RenoTahoe International Airport and various components of employment series in Reno MSA, a detailed description of the data is in order.

Monthly local employment data for Reno MSA from January 1992 through September 2002 is used as a proxy for regional economic activity, provided by the Nevada Department of Employment Training and Rehabilitation (DETR). The employment series on four sectors of the local economy are used: manufacturing, wholesale trade, retail and finance, insurance and real estate (F.I.R.E). The Reno-Tahoe International Airport publishes monthly air cargo volumes. Similarly, the air cargo series data are from January 1992 through September 2002. The employment data for the three targeted industry sectors is presented in Table 1.

As shown in Table 1, the Reno MSA employment series for manufacturing, wholesale and retail in 2002 follow the national trend. The Reno MSA average manufacturing employment dropped by 1.22 percent between 2001 and 2002; whereas, the Reno MSA average wholesale employment remained the same, the Reno MSA average retail employment increased by 1.12 percent in 2002 and the Reno MSA average F.I.R.E employment increased by 1.94 percent in 2002.

The annual freight volume through the RTIA and employment summary are presented in Table 2, which also presents the annual rates of change for each series. As can be seen from the data in Table 2, RTIA air cargo shipments made a healthy recovery in 2002 showing an increase of 5.8 percent over 2001. Also, the rates of change in the air cargo volumes and the rates of change in the total employment in the four targeted sectors seem to follow the same pattern, with the growth in air cargo lagging approximately one year behind the growth in employment. Slow downs in employment seem to be reflected more quickly by reductions in the rate of growth or even shrinkage in air cargo volumes.

To have an in depth analysis of air cargo in Northern Nevada, the monthly data of mail and freight are split into in terms of inbound and outbound air cargo shipments at RTIA. The data are shown in Table 3 for 2002 . The shipment of airmail at RTIA was over 5.9 million pounds in 2002, showing a decline of 59 percent from 2001. This follows the trend of significant decline in airmail in 2002 in major airports in the country caused primarily by tighter restrictions imposed by federal government on mail shipments abroad commercial aircraft. In 2002, the inbound airmail was about 72 percent of total airmail at RTIA compared with 72 percent in 2001 . The ratio of the volume of inbound to outbound airmail at RTIA in 2002 was 2.58 .

The airfreight shipments at RTIA had a strong performance in 2002. A total of over 100.3 million pounds of airfreight was shipped in 2002, an increase of 17 percent over the total airfreight shipments of over 85.9 million pounds in 2001. There was more outbound airfreight than inbound airfreight at RTIA, amounting to nearly identical ratio of outbound to inbound airfreight between 2001 and 2002: 1.13 in 2001 and 1.11 in 2002. As was indicated earlier, the total air cargo shipments at RTIA (air and mail) were over 106 million pounds in 2002, showing an increase of 5.8 percent over 2001.

\section{EMPIRICAL RESULTS}

The variables under study are generally nonstationary in levels, while stationary when transformed to percentage changes by both the Augmented Dickey-Fuller (ADF) and the Phillips-Perron (PP) tests. These results are shown in Table 4. To ensure the robustness of the tests, three versions of the ADF and PP regressions with intercept, with trend and intercept, and with neither the intercept nor the trend variable are estimated. The test results are consistent and insensitive to the type of specification. Thus, while cointegration tests maybe appropriate to investigate the long-run equilibrium relationship between variable levels, we estimate several regressions for percentage changes of employment and cargo shipments. 
Table 5 reports regression findings for percentage change in employment in four sectors of the regional economy (PFEP: percentage change in employment of finance, insurance and real estate; PMEP: percentage change of employment in manufacturing; PREP: percentage change in employment of retail; and PWEP: percentage change in employment of wholesale) and cargo shipment percentage changes. Up to eight leading and lagging cargo variables are included in the regression Equations as determined by the Akaike Information Criterion (AIC). Equation (1) allows a preliminary analysis of the dynamic relationship between air cargo shipments and employment changes in Reno MSA.

Employment in retail, wholesale, and manufacturing appear to lead cargo shipments. This is evidenced by significant coefficients of several lead cargo variables. The finance sector does not seem to be strongly related to cargo shipment changes. Thus, it is plausible to assume that cargo shipment activities fluctuate with the local employment in three out of four sectors under consideration. The lagged cargo variables in all Equations are generally insignificant and demonstrate signs that are theoretically and intuitively implausible.

Following the findings presented in Table 5, we theorize that employment in various sectors of the economy may react differently to expected and unexpected cargo shipment activities. For example, unexpected cargo shipments activities may have more significant effect on employment than expected fluctuations. Furthermore, there might be a lagged reaction in employment in case of either expected or unexpected ebbs and flows in cargo shipment. Thus, we estimate Equations (2) through (4) which account for these possibilities.

Table 6 shows these findings. The top panel of Table 6 reports the relationship between employment in four sectors and the expected and unexpected cargo shipments. Empirical findings support the notion that expected cargo shipments and employment are not correlated. However, the unexpected cargo shipments seem to lead employment in three out of four sectors in the study.

The second and third panels of Table 6 report the findings of testing for the leading role of the expected and unexpected cargo activities in employment fluctuations. While we find that unexpected changes in cargo shipments lead effect employment in some sectors, the direction of changes in employment are erratic and implausible. For instance, while retail and wholesale sector employment are immediately and positively affected by the unexpected fluctuations in air cargo shipments, finance manufacturing sector employment show no gain. It further appears that increased cargo activity in previous months negatively affects current employment in all sectors except manufacturing. These findings are unconvincing. The last panel of the Table verifies that current and past expected cargo shipments are not correlated with current employment fluctuations in the Reno/ Tahoe area.

To further examine the relationship between employment in retail and wholesale sectors of Reno MSA economy and unexpected cargo shipments, we re estimate a variation of Equation (3) with leading and lagging values of cargo shipments as explanatory variables. Table 7 reports the results of this investigation. Once again, employment changes lead unexpected cargo shipments of future months. For instance, changes in retail and wholesale sector employment affect result in unexpected cargo activities up to three months. These findings are plausible in the sense that rises in employment and the income it generates, contribute to cargo shipment activities which had not been foreseen.. Furthermore, employment fluctuations in these sectors lead unexpected cargo shipments. These findings corroborate those reported in Table 5. The remainder of the empirical investigation is devoted to Granger causality tests and the long-run equilibrium analysis between cargo shipments and employment fluctuations.

In order to investigate the long-run equilibrium relationship between sector employment and cargo shipment in Reno-Tahoe International Airport, we conduct the Johansen -Juselius conitegration test. It is necessary to determine the lag structure of the underlying VAR system. We determine the VAR lag dynamics by Akaike, and Shwarz criteria (AIC and SIC), respectively. We further apply the adjusted likelihood ration test to break the tie one way or the other if AIC and SIC indicate conflicting lag structures. The tie beaker test may be necessary because AIC often tends toward longer lag length than the SIC. Table 8 reports test results for the lag structure determination.

Before estimating the cointegrating VAR models it is necessary to determine the order of the VAR in the estimation. To this end we test unrestricted VAR models up to twenty four with lag dimensions. Akaike, Shwarz, 
criteria and the adjusted likelihood ration tests (ALR) are employed for this purpose. The AIC often tends toward longer lag order than the SBC. In the interest of avoiding over or under parameterization of the VAR models, we use the ALR as tiebreaker. Table 8 illustrates the findings of these tests.

Four VAR models of orders 3, 2, 3, and 2 are estimated. The Granger block causality tests indicate that the hypothesis on no causality between employment and cargo shipment is rejected in three out of four cases. Thus, as shown in Tables above, wholesale, retail, and finance, insurance and real estate sector employment in Reno MSA affects cargo shipments at the Reno/ Tahoe airport. Furthermore, Table 9 reports a long-run equilibrium between the manufacturing and wholesale sector employment. The maximum eigenvalue and trace tests are significant for employment and cargo at the 95 percent level. Thus, even though manufacturing did not show short run correlation or causal relationship with cargo shipments, in the long-run such relationship is supported by the statistical evidence.

To examine the responses of the cointegrating vectors to shocks in air cargo shipments at RTIA, we analyze the impulse responses. The generalized impulse responses show that the effect of air cargo shocks on the long-run equilibrium relations are most pronounced in earlier month and tend to taper off gradually. However shock effects on the two cointegrating vectors are quite different. While the impulse response indicates the shock effects tend to weaken steadily in the case of cargo-manufacturing employment that is not true of wholesale employment and air cargo long-run equilibrium relationship. These findings support previous observation that wholesale employment and air cargo shipments are strongly correlated. Figures 1 and 2 illustrate the generalized impulse responses resulting from the VAR models for manufacturing and wholesale employment.

\section{SUMMARY AND CONCLUSIONS}

This paper investigates the relationship between employment in four sectors of Reno MSA and cargo shipment from Reno-Tahoe International Airport. A number of statistical tools comprise the mainstay of our methodology. Our data consist of monthly cargo shipments and employment statistics for Reno MSA from January 1992 through September 2002. Employment data for finance, manufacturing, wholesale trade and retail are provided by the Nevada Department of Employment Training and Rehabilitation (DETR). Our findings verify that employment in retail and wholesale sectors of Reno MSA is positively related with unexpected cargo shipments. Furthermore, employment fluctuations in these sectors lead unexpected cargo shipments.

To examine the long-run relationship between employment and cargo shipments, we conduct cointegration tests and analyze responses of the cointegrating vectors to shocks in cargo shipments. We find cointegration between employment in manufacturing and wholesale and cargo shipments. The generalized impulse responses show that the effect of cargo shocks on the long-run equilibrium relations are most pronounced in earlier month and tend to taper off gradually. While the impulse response indicates the shock effects tend to weaken steadily in the case of cargomanufacturing employment, that is not true of wholesale employment and cargo long-run equilibrium relationship. These findings support previous observation that wholesale employment and cargo shipments are strongly correlated. In summary, employment in all sectors of Reno MSA except in finance are either in the long-run or in the short-run related with cargo shipment activities of Reno-Tahoe International Airport. 
Table 1: Annual Average Employment In Three Sect Of Reno MSA, And Rates Of Change In Each Sector

\begin{tabular}{|c|c|c|c|c|c|c|c|c|}
\hline Year & $\begin{array}{c}\text { Reno MSA } \\
\text { Average } \\
\text { Mfg. } \\
\text { Employment } \\
\text { (thousands) }\end{array}$ & $\begin{array}{c}\text { Annual } \\
\text { Percent } \\
\text { Change }\end{array}$ & $\begin{array}{c}\text { Reno MSA } \\
\text { Average } \\
\text { Wholesale } \\
\text { Employment } \\
\text { (thousands) }\end{array}$ & $\begin{array}{l}\text { Annual } \\
\text { Percent } \\
\text { Change }\end{array}$ & $\begin{array}{c}\text { Reno MSA } \\
\text { Average } \\
\text { Retail } \\
\text { Employment } \\
\text { (thousands) }\end{array}$ & $\begin{array}{l}\text { Annual } \\
\text { Percent } \\
\text { Change }\end{array}$ & \begin{tabular}{|l} 
Reno MSA \\
Average \\
F.I.R.E. \\
Employment \\
(thousand)
\end{tabular} & $\begin{array}{l}\text { Annual } \\
\text { Percent } \\
\text { Change }\end{array}$ \\
\hline 1992 & 9.03 & ---- & 8.77 & ---- & 24.81 & ----- & 7.12 & ---- \\
\hline 1993 & 10.33 & 14.40 & 8.87 & 1.14 & 25.10 & 1.18 & 7.18 & 2.99 \\
\hline 1994 & 11.95 & 15.74 & 9.32 & 5.08 & 26.09 & 3.95 & 7.49 & 4.29 \\
\hline 1995 & 12.37 & 3.49 & 9.95 & 6.80 & 27.23 & 4.38 & 7.40 & -1.22 \\
\hline 1996 & 13.08 & 5.80 & 10.88 & 9.38 & 28.18 & 3.49 & 7.51 & 1.46 \\
\hline 1997 & 13.37 & 2.17 & 11.36 & 4.36 & 29.27 & 3.84 & 8.00 & 6.55 \\
\hline 1998 & 13.66 & 2.18 & 12.03 & 5.94 & 29.17 & 0.34 & 8.38 & 4.69 \\
\hline 1999 & 13.34 & -2.32 & 11.71 & 2.70 & 30.60 & 4.91 & 8.27 & -1.29 \\
\hline 2000 & 14.03 & 5.12 & 12.36 & 5.55 & 31.44 & 2.75 & 8.79 & 6.35 \\
\hline 2001 & 14.68 & 4.69 & 12.39 & 0.27 & 31.25 & 0.61 & 9.03 & 2.65 \\
\hline 2002 & 14.50 & -1.22 & 12.40 & 0.00 & 31.60 & 1.12 & 9.20 & 1.94 \\
\hline
\end{tabular}

Note: The employment data for 2002 are through the end of September.

Table 2: Annul Air Cargo Volume Through Reno-Tahoe International Airport And Total Average Employment Of Four Indus Sectors In Reno MSA, With Rates Of Change

\begin{tabular}{|c|c|c|c|c|c|}
\hline Year & $\begin{array}{c}\text { Annual } \\
\text { Air Cargo } \\
\text { Weight } \\
\text { (pounds) }\end{array}$ & $\begin{array}{l}\text { Annual } \\
\text { Percent } \\
\text { Change }\end{array}$ & $\begin{array}{c}\text { Reno MSA } \\
\text { Average } \\
\text { Employment } \\
\text { Targeted } \\
\text { Industries } \\
\text { (thousands) }\end{array}$ & $\begin{array}{l}\text { Annual } \\
\text { Percent } \\
\text { Change }\end{array}$ & $\begin{array}{c}3 \text { Year } \\
\text { Moving } \\
\text { Average } \\
4 \text { Target } \\
\text { Sectors }\end{array}$ \\
\hline 1992 & $28,205,981$ & ---- & 42.60 & --- & ----- \\
\hline 1993 & $28,483,722$ & 0.98 & 44.29 & 3.97 & \\
\hline 1994 & $34,869,510$ & 22.42 & 47.36 & 6.92 & \\
\hline 1995 & $42,866,729$ & 22.93 & 49.55 & 4.63 & 5.17 \\
\hline 1996 & $57,292,262$ & 33.65 & 52.15 & 5.25 & 5.60 \\
\hline 1997 & $88,124,018$ & 53.81 & 53.99 & 3.53 & 4.47 \\
\hline 1998 & $96,245,828$ & 9.22 & 54.86 & 1.61 & 3.46 \\
\hline 1999 & $104,003,193$ & 8.06 & 55.65 & 1.44 & 2.19 \\
\hline 2000 & $111,681,525$ & 7.38 & 57.83 & 3.91 & 2.32 \\
\hline 2001 & $100,523,574$ & -9.99 & 58.33 & 0.86 & 2.07 \\
\hline 2002 & $106,377,207$ & 5.8 & 58.50 & 0.30 & 1.69 \\
\hline
\end{tabular}

Note: The employment data for 2002 are through the end of September. 
Table 3: Mail And Freight Shipments In Reno-Tahoe International Airport In 2002

\begin{tabular}{|c|c|c|c|c|c|c|c|c|}
\hline & & & & & & & $\begin{array}{c}\text { Ratio of } \\
\text { Inbound } \\
\text { to } \\
\text { Thatio of } \\
\text { Outbound } \\
\text { Outbound } \\
\text { to } \\
\text { Inbound } \\
\text { Freight }\end{array}$ \\
\hline Month & Mail & & & Freight & & & & \\
January & 137,922 & 366,150 & 504,072 & $4,522,387$ & $3,976,230$ & $8,498,617$ & 2.6548 & 1.1374 \\
February & 166,289 & 346,012 & 512,301 & $4,038,307$ & $3,384,932$ & $7,423,239$ & 2.0808 & 1.1930 \\
March & 163,423 & 378,357 & 541,780 & $4,508,835$ & $3,773,897$ & $8,282,732$ & 2.3152 & 1.1947 \\
April & 105,074 & 366,609 & 471,683 & $4,195,611$ & $3,670,085$ & $7,865,696$ & 3.4891 & 1.1432 \\
May & 152,791 & 381,296 & 534,087 & $4,501,853$ & $3,873,605$ & $8,375,458$ & 2.4955 & 1.1622 \\
June & 93,580 & 327,232 & 420,812 & $4,392,184$ & $3,835,691$ & $8,227,875$ & 3.4968 & 1.1451 \\
July & 65,042 & 332,185 & 397,227 & $4,355,547$ & $3,749,644$ & $8,105,191$ & 5.1072 & 1.1616 \\
August & 87,375 & 284,294 & 371,669 & $4,824,560$ & $4,300,665$ & $9,125,225$ & 3.2537 & 1.1218 \\
September & 44,321 & 260,366 & 304,687 & $4,053,679$ & $3,753,634$ & $7,807,313$ & 5.8746 & 1.0799 \\
October & 54,259 & 311,065 & 365,324 & $4,424,591$ & $4,349,327$ & $8,773,918$ & 5.7330 & 1.0173 \\
November & 107,387 & 353,867 & 461,254 & $4,219,669$ & $4,105,686$ & $8,325,355$ & 3.2952 & 1.0278 \\
December & 490,421 & $\mathbf{6 0 3 , 2 0 4}$ & $1,093,625$ & $5,283,809$ & $4,304,258$ & $9,588,067$ & 1.2300 & 1.2276 \\
\hline Total & $\mathbf{1 , 6 6 7 , 8 8 4}$ & $\mathbf{4 , 3 1 0 , 6 3 7}$ & $\mathbf{5 , 9 7 8 , 5 2 1}$ & $\mathbf{5 3 , 3 2 1 , 0 3 2}$ & $\mathbf{4 7 , 0 7 7 , 6 5 4}$ & $\mathbf{1 0 0 , 3 9 8 , 6 8 6}$ & $\mathbf{2 . 5 8 4 5}$ & $\mathbf{1 . 1 3 2 6}$ \\
\hline
\end{tabular}

Note: Total cargo Shipments, sum of freight and mail shipments, is 106,377,207 in Reno-Tahoe International Airport in 2002.

Table 4: Unit Root Tests

Panel A: Level Series

\begin{tabular}{|c|c|c|c|c|}
\hline Variable & ADF & $\mathbf{P P}$ & ADF & PP \\
\hline $\mathrm{CG}_{a}$ & -1.121 & -1.462 & $-5.879^{* * *}$ & $-23.892^{* * * *}$ \\
\hline $\mathrm{CG}_{b}$ & -1.950 & $-4.331^{* * * *}$ & $-6.327^{* * * *}$ & $-24.887^{* * * *}$ \\
\hline $\mathrm{CG}_{c}$ & 0.811 & 0.340 & $-4.512^{* * * *}$ & $-20.303^{* * *}$ \\
\hline $\mathrm{FEP}_{a}$ & 0.009 & -0.005 & $-5.347^{* * *}$ & $-13.041^{* * * *}$ \\
\hline $\mathrm{FEP}_{b}$ & -3.072 & $-3.517^{* *}$ & $-5.348^{* * *}$ & $-13.000^{* * * *}$ \\
\hline $\mathrm{FEP}_{c}$ & 2.324 & 2.388 & $-4.663^{* * *}$ & $-12.405^{* * *}$ \\
\hline $\mathrm{MEP}_{a}$ & -2.894 & $-3.280^{* *}$ & $-3.377^{* * * *}$ & $-10.828^{* * * *}$ \\
\hline $\mathrm{MEP}_{b}$ & -2.174 & -2.048 & $-3.947^{* * *}$ & $-11.632^{* * * *}$ \\
\hline $\mathrm{MEP}_{c}$ & 1.99 & 2.92 & $-2.866^{* * *}$ & $-9.875^{* * *}$ \\
\hline $\operatorname{REP}_{a}$ & -1.139 & -1.314 & $-7.036^{* * *}$ & $-11.924^{* * * *}$ \\
\hline $\mathrm{REP}_{b}$ & $-4.371^{* * * *}$ & $-5.223^{* * *}$ & $-7.025^{* * *}$ & $-11.891^{* * * *}$ \\
\hline $\mathrm{REP}_{c}$ & 1.563 & 1.25 & $-6.619^{* * *}$ & $-11.673^{* * * *}$ \\
\hline $\mathrm{WEP}_{a}$ & -1.257 & -1.224 & $-5.746^{* * * *}$ & $-11.720^{* * * *}$ \\
\hline $\mathrm{WEP}_{b}$ & -1.525 & -1.683 & $-5.920^{* * *}$ & $-11.796^{* * *}$ \\
\hline $\mathrm{WEP}_{c}$ & 1.984 & 2.208 & $-4.942^{* * *}$ & $-11.179^{* * * *}$ \\
\hline
\end{tabular}

Notes: CG, FEP, MEP, REP, and WEP represent the air cargo shipments at Reno-Tahoe International Airport, employment in 
finance, insurance and real estate, manufacturing, retail, and wholesale sector employment sectors in Reno MSA, respectively.

Percentage changes in each variable are the natural logarithm ratios, $\operatorname{Ln}\left(\mathrm{x}_{t} / \mathrm{x}_{t-1}\right)$.

(a), (b), and (c), represent Augmented Dickey-Fuller(ADF) and Phillips-Perron (PP) unit root test with intercept, with trend and intercept and with neither trend nor intercept, respectively. The ADF entails estimating $\Delta \mathrm{x}_{t}=\alpha+\beta \mathrm{x}_{t-1}+\gamma_{j} \Sigma_{j=1}^{k} \Delta \mathrm{x}_{t-j}+$

$u_{t}$ and testing the null hypothesis that $\beta=0$ versus the alternative of $\beta<0$, for any $\mathrm{x}$. The PP test requires estimating $\Delta \mathrm{x}_{t}=\alpha+$

$\beta \mathrm{x}_{t-1}+u_{t}$ and testing the null hypothesis $\beta=0$ versus the alternative of $\beta<0$. The PP test may be more appropriate if autocorrelation in the series under investigation is suspected. The number of lags on the right-hand-side of ADF regressions as suggested by AIC and SIC.

$*, * *$, and $* * *$ represent $10 \%, 5 \%$, and $1 \%$ significance levels, respectively.

Table 5: The Test Of Lead-Lag Relationship Between Employment And The Cargo Shipment Using Equation (1)

Employment $_{t}=\alpha_{1}+\theta_{i} C G_{t-i}+$ error $_{t}$

\begin{tabular}{|c|c|c|c|c|}
\hline & PFEP & PMEP & PREP & PWEP \\
\hline$\alpha$ & $\begin{array}{c}0.002 \\
(0.719)\end{array}$ & $\begin{array}{c}0.001 \\
(0.280)\end{array}$ & $\begin{array}{l}-0.002 \\
(0.412)\end{array}$ & $\begin{array}{c}0.0002 \\
(0.106)\end{array}$ \\
\hline $\mathrm{CG}_{t-8}$ & $\begin{array}{c}-0.008 \\
(-0.742)\end{array}$ & $\begin{array}{c}-0.004 \\
(-0.360)\end{array}$ & $\begin{array}{c}-0.009 \\
(-0.446)\end{array}$ & $\begin{array}{c}0.013 \\
(1.141)\end{array}$ \\
\hline $\mathrm{CG}_{t-7}$ & $\begin{array}{c}0.010 \\
(0.750)\end{array}$ & $\begin{array}{c}0.005 \\
(0.380)\end{array}$ & $\begin{array}{c}-0.025 \\
(-1.061)\end{array}$ & $\begin{array}{c}0.018 \\
(1.299)\end{array}$ \\
\hline $\mathrm{CG}_{t-6}$ & $\begin{array}{c}0.007 \\
(0.519)\end{array}$ & $\begin{array}{c}0.012 \\
(0.924)\end{array}$ & $\begin{array}{c}-0.245 \\
(-1.025)\end{array}$ & $\begin{array}{c}0.0134 \\
(0.987)\end{array}$ \\
\hline $\mathrm{CG}_{t-5}$ & $\begin{array}{l}-0.003 \\
(-0.239)\end{array}$ & $\begin{array}{c}-0.008 \\
(-0.625)\end{array}$ & $\begin{array}{c}-0.036 \\
(-1.513)\end{array}$ & $\begin{array}{c}0.009 \\
(0.671)\end{array}$ \\
\hline $\mathrm{CG}_{t-4}$ & $\begin{array}{c}-0.002 \\
(-0.116)\end{array}$ & $\begin{array}{l}-0.005 \\
(0.367)\end{array}$ & $\begin{array}{r}0.0353 \\
(-1.501)\end{array}$ & $\begin{array}{c}0.001 \\
(0.080)\end{array}$ \\
\hline $\mathrm{CG}_{t-3}$ & $\begin{array}{c}-0.004 \\
(-0.351)\end{array}$ & $\begin{array}{c}0.011 \\
(0.922)\end{array}$ & $\begin{array}{l}-0.048^{* *} \\
(-2.196)\end{array}$ & $\begin{array}{c}-0.003 \\
(-0.226)\end{array}$ \\
\hline $\mathrm{CG}_{t-2}$ & $\begin{array}{c}-0.0191 \\
(-1.524)\end{array}$ & $\begin{array}{c}0.015 \\
(1.250)\end{array}$ & $\begin{array}{c}-0.009 \\
(-0.424)\end{array}$ & $\begin{array}{c}0.004 \\
(0.302)\end{array}$ \\
\hline $\mathrm{CG}_{t-1}$ & $-0.022^{*}$ & 0.021 & -0.010 & -0.009 \\
\hline $\mathrm{CG}$ & $\begin{array}{c}(--1.768) \\
0.025^{* *} \\
(2.003)\end{array}$ & $\begin{array}{c}(1.785) \\
0.019 \\
(1.651)\end{array}$ & $\begin{array}{c}(-0.475) \\
0.511^{* *} \\
(2.386)\end{array}$ & $\begin{array}{c}(-0.681) \\
0.028^{* *} \\
(2.245)\end{array}$ \\
\hline $\mathrm{CG}_{t+1}$ & $\begin{array}{c}0.018 \\
(1.471)\end{array}$ & $\begin{array}{c}0.006 \\
(0.563)\end{array}$ & $\begin{array}{c}0.042^{*} \\
(1.984)\end{array}$ & $\begin{array}{c}0.015 \\
(1.227)\end{array}$ \\
\hline $\mathrm{CG}_{t+2}$ & $\begin{array}{c}-0.003 \\
(-0.205)\end{array}$ & $\begin{array}{c}0.002 \\
(0.186)\end{array}$ & $\begin{array}{c}0.022 \\
(1.051)\end{array}$ & $\begin{array}{c}0.013 \\
(1.022)\end{array}$ \\
\hline $\mathrm{CG}_{t+3}$ & $\begin{array}{c}0.012 \\
(0.964)\end{array}$ & $\begin{array}{c}0.011 \\
(0.992)\end{array}$ & $\begin{array}{c}0.046^{* *} \\
(2.206)\end{array}$ & $\begin{array}{c}0.030^{* * *} \\
(2.439)\end{array}$ \\
\hline $\mathrm{CG}_{t+4}$ & .009 & $0.020^{*}$ & 0.031 & $0.022^{*}$ \\
\hline
\end{tabular}


Journal of Business \& Economics Research - February 2007

Volume 5, Number 2

$\begin{array}{ccccc} & (0.707) & (1.669) & (1.42) & (1.719) \\ \mathrm{CG}_{t+5} & -0.007 & 0.030^{* *} & -0.005 & -0.0001 \\ & (-0.539) & (2.421) & (-0.217) & (-0.013) \\ \mathrm{CG}_{t+6} & 0.011 & 0.001 & -0.002 & -0.022 \\ & (0.841) & (0.146) & (-0.0716) & (-1.616) \\ \mathrm{CG}_{t+7} & 0.012 & 0.006 & 0.015 & -0.008 \\ & (0.905) & (0.484) & (0.746) & (-0.601) \\ \mathrm{CG}_{t+8} & -0.002 & -0.012 & 0.017 & -0.007 \\ & (-0.204) & (-1.110) & (0.837) & (-0.606) \\ & \bar{R}^{2}=0.085 & \bar{R}^{2}=0.005 & \bar{R}^{2}=0.126 & \bar{R}^{2}=0.113\end{array}$

Notes: The lead/lag dimension of the independent variable is determined by the minimum AIC. All variables are in percentage change. $* * *$, and $* * *$ represent $10 \%, 5 \%$, and $1 \%$ significance levels, respectively.

Table 6: OLS Estimates Of Equations (2) Through (4)

$$
\begin{aligned}
& \text { Employment }_{t}=\alpha_{1}+\beta_{i} \Sigma U X C G_{t-1}+\theta_{i} \Sigma X C G_{t-i}+\text { error }_{t} \\
& \text { Employment }_{t}=\alpha_{1}+\beta_{i} \Sigma U X C G_{t-1}+\text { error }_{t} \\
& \text { Employment }_{t}=\alpha_{1}+\theta_{i} \Sigma X C G_{t-i}+\text { error }_{t}
\end{aligned}
$$

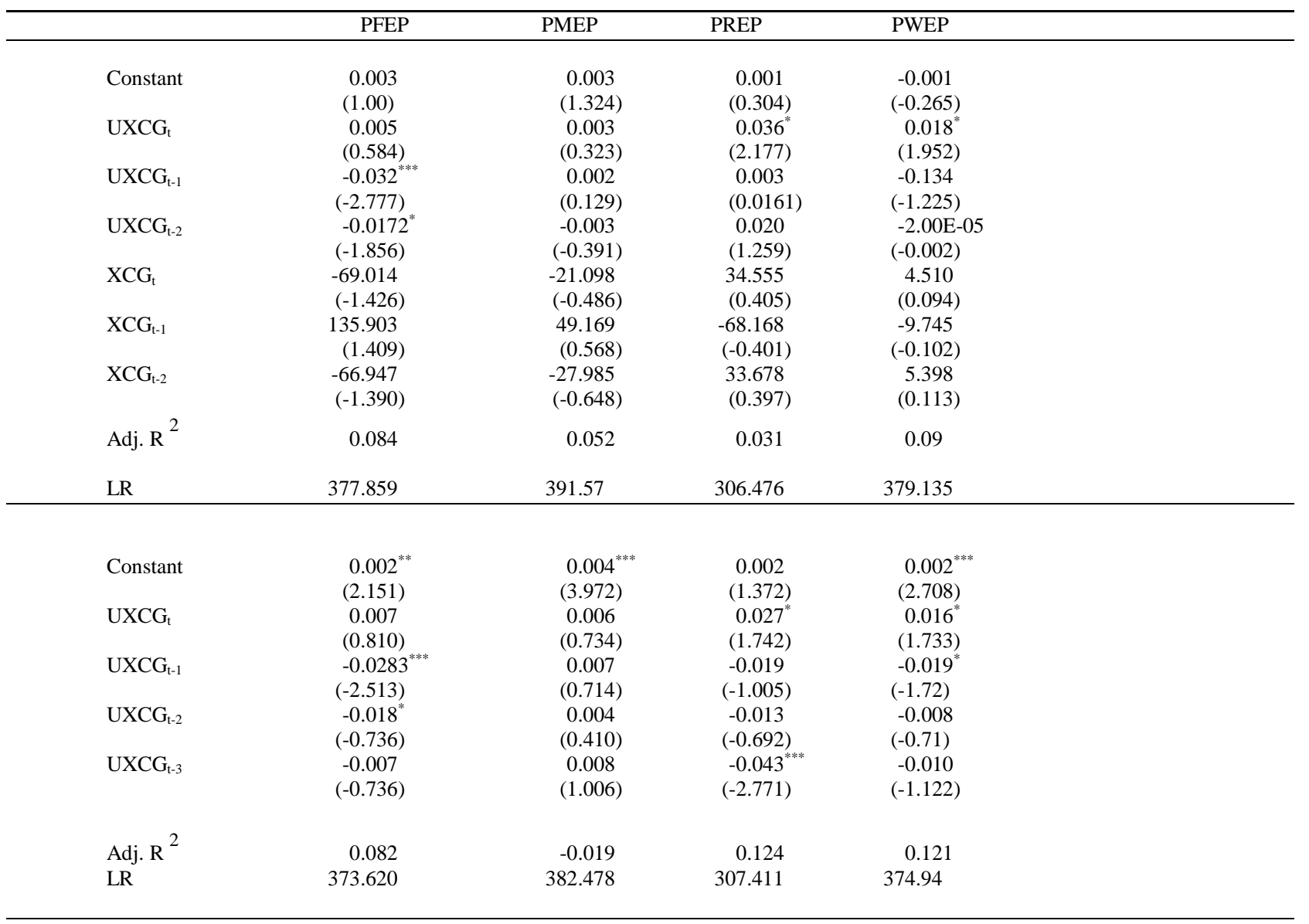




$\begin{array}{lcccc}\text { Constant } & 0.002 & 0.004 & 0.001 & -0.001 \\ & (0.806) & (1.475) & (0.256) & (-0.254) \\ \mathrm{XCG}_{\mathrm{t}} & 74.527 & 21.876 & -81.407 & 106.115 \\ & (0.496) & (0.173) & (-0.314) & (0.716) \\ \mathrm{XCG}_{\mathrm{t}-1} & -249.065 & -80.425 & 267.242 & -302.181 \\ & (-0.561) & (-0.215) & (0.349) & (-0.690) \\ \mathrm{XCG}_{\mathrm{t}-2} & 272.875 & 103.019 & -289.699 & 285.849 \\ & (0.616) & (0.276) & (-0.379) & (0.0654) \\ \mathrm{XCG}_{\mathrm{t}-3} & -98.363 & -44.393 & 103.930 & -89.613 \\ & (-0.657) & (-0.352) & (.404) & (-0.608) \\ \text { Adj. } \mathrm{R} & -0.024 & 0.02 & -0.031 & -0.008 \\ \text { LR } & 366.766 & 388.184 & 298.670 & 368.431\end{array}$

Notes: Employment variables are the dependent variables in percentage change. The expected (with prefix X) and unexpected (UX) components of the variables are derived from the Hodrick-Prescot method. Instruments employed in the 2SLS estimates are constant, CG, FEP, MEP, REP, and WEP. The lag length in regressions is determined by the AIC.

$*$, ** and $* * *$ represent $10 \%, 5 \%$, and $1 \%$ significance levels, respectively.

Table 7: Unexpected Cargo Shipment And Employment Using Equation (3)

\begin{tabular}{|c|c|c|c|c|}
\hline Employn & $e n t_{t}=\alpha_{1}+$ & $X C G_{t-i}+e$ & & (3) \\
\hline & PFEP & PMEP & PREP & PWEP \\
\hline$\alpha$ & $\begin{array}{c}0.002 \\
(0.719)\end{array}$ & $\begin{array}{c}0.001 \\
(0.280)\end{array}$ & $\begin{array}{l}-0.002 \\
(0.412)\end{array}$ & $\begin{array}{c}0.0002 \\
(0.106)\end{array}$ \\
\hline $\mathrm{UXCG}_{t-3}$ & $\begin{array}{c}-0.004 \\
(-0.351)\end{array}$ & $\begin{array}{c}0.011 \\
(0.922)\end{array}$ & $\begin{array}{l}-0.048^{* *} \\
(-2.196)\end{array}$ & $\begin{array}{c}-0.003 \\
(-0.226)\end{array}$ \\
\hline $\mathrm{UXCG}_{t-2}$ & $\begin{array}{l}-0.0191 \\
(-1.524)\end{array}$ & $\begin{array}{c}0.015 \\
(1.250)\end{array}$ & $\begin{array}{c}-0.009 \\
(-0.424)\end{array}$ & $\begin{array}{c}0.004 \\
(0.302)\end{array}$ \\
\hline $\mathrm{UXCG}_{t-1}$ & $\begin{array}{c}-0.022^{*} \\
(-1.768)\end{array}$ & $\begin{array}{c}0.021 \\
(1.785)\end{array}$ & $\begin{array}{c}-0.010 \\
(-0.475)\end{array}$ & $\begin{array}{c}-0.009 \\
(-0.681)\end{array}$ \\
\hline UXCG & $\begin{array}{c}0.025^{* *} \\
(2.003)\end{array}$ & $\begin{array}{c}0.019 \\
(1.651)\end{array}$ & $\begin{array}{c}0.511^{* *} \\
(2.386)\end{array}$ & $\begin{array}{c}0.028^{* * *} \\
(2.245)\end{array}$ \\
\hline $\mathrm{UXCG}_{t+1}$ & $\begin{array}{c}0.018 \\
(1.471)\end{array}$ & $\begin{array}{c}0.006 \\
(0.563)\end{array}$ & $\begin{array}{c}0.042^{*} \\
(1.984)\end{array}$ & $\begin{array}{c}0.015 \\
(1.227)\end{array}$ \\
\hline $\mathrm{UXCG}_{t+2}$ & $\begin{array}{c}-0.003 \\
(-0.205)\end{array}$ & $\begin{array}{c}0.002 \\
(0.186)\end{array}$ & $\begin{array}{c}0.022 \\
(1.051)\end{array}$ & $\begin{array}{c}0.013 \\
(1.022)\end{array}$ \\
\hline $\mathrm{UXCG}_{t+3}$ & $\begin{array}{c}0.012 \\
(0.964) \\
\bar{R}^{2}=0.085 \\
\end{array}$ & $\begin{array}{c}0.011 \\
(0.992) \\
\bar{R}^{2}=0.005 \\
\end{array}$ & $\begin{aligned} & 0.046^{* *} \\
&(2.206) \\
& \bar{R}^{2}= 0.126 \\
&\end{aligned}$ & $\begin{array}{r}0.030^{* *} \\
(2.439) \\
\bar{R}^{2}=0.113 \\
\end{array}$ \\
\hline
\end{tabular}

Notes: The lead/lag dimension of the independent variable is determined by the minimum AIC. All variables are in percentage change. Unexpected cargo series is stationary at the 1 percent level $(\mathrm{ADF}=-6.53$, and $\mathrm{PP}=-25.69)$. *, **, and *** represent $10 \%$, $5 \%$, and $1 \%$ significance levels, respectively. 


\begin{tabular}{|c|c|c|c|c|}
\hline & AIC & SIC & ALR & $\begin{array}{l}\text { Block Causality }\left(\chi^{2}\right) \\
\text { H0:No Causality }\end{array}$ \\
\hline PFEP & 2 & 3 & 3 or 4 & $12.20^{* * *}$ \\
\hline PMEP & 2 & 2 & 2 or 3 & 0.60 \\
\hline PREP & 3 & 2 & 2 or 3 & $15.50^{* * * *}$ \\
\hline PWEP & 2 & 2 & 2 or 3 & $8.97^{* * * *}$ \\
\hline
\end{tabular}

Notes: A dummy variable that takes on value of one for September 11, 2000 is included in VARs.

$*, * *$, and $* * *$ represent $10 \%, 5 \%$, and $1 \%$ significance levels, respectively.

Table 9: Long-Term Equilibrium: Johansen-Juselius Maximum Likelihood Procedure

Cointegration LR Test Based on Maximal Eigenvalue and Trace of the Stochastic Matrix Variables included in the cointegrating vector

$\begin{array}{llll}\text { CG\&FEP } & \text { CG\&MEP } & \text { CG\&REP } & \text { CG\&WEP }\end{array}$

\begin{tabular}{|c|c|c|c|c|c|}
\hline \multicolumn{6}{|c|}{ Panel A: } \\
\hline Но & $\mathrm{Ha}$ & \multicolumn{4}{|c|}{$\lambda_{\text {max }}$} \\
\hline$r=0$ & & $\begin{array}{l}7.54^{\mathrm{a}} \\
1.57^{\mathrm{b}}\end{array}$ & $\begin{array}{l}15.76^{\mathrm{a}^{* * *}} \\
12.30^{\mathrm{b}}\end{array}$ & $\begin{array}{l}7.63^{\mathrm{a}} \\
2.69^{\mathrm{b}}\end{array}$ & $\begin{array}{l}12.96^{\mathrm{a}^{* *}} \\
10.62^{\mathrm{b}}\end{array}$ \\
\hline $\mathrm{r} \leq 1$ & $\mathrm{r}=2$ & $\begin{array}{l}1.57^{\mathrm{a}} \\
0.27^{\mathrm{b}}\end{array}$ & $\begin{array}{l}0.03^{\mathrm{a}} \\
6.88^{\mathrm{b}^{*}}\end{array}$ & $\begin{array}{l}0.61^{\mathrm{a}} \\
1.74^{\mathrm{b}}\end{array}$ & $\begin{array}{l}0.16^{\mathrm{a}} \\
3.84^{\mathrm{b}}\end{array}$ \\
\hline & & \multicolumn{4}{|c|}{$\lambda_{\text {trace }}$} \\
\hline \multicolumn{6}{|c|}{ Panel B: } \\
\hline & $r \geq 1$ & $\begin{array}{l}9.11^{\mathrm{a}} \\
1.84^{\mathrm{b}}\end{array}$ & $\begin{array}{l}15.79^{a^{* * *}} \\
19.19^{b^{* * *}}\end{array}$ & $\begin{array}{l}8.24^{\mathrm{a}} \\
4.43^{\mathrm{b}}\end{array}$ & $\begin{array}{l}86.98^{\mathrm{a}^{* * * *}} \\
14.46^{\mathrm{b}}\end{array}$ \\
\hline $\mathrm{r} \leq 1$ & $r \geq 2$ & $\begin{array}{l}1.57^{\mathrm{a}} \\
0.27^{\mathrm{b}}\end{array}$ & $\begin{array}{l}0.03^{\mathrm{a}} \\
6.88^{b^{*}}\end{array}$ & $\begin{array}{l}0.61^{\mathrm{a}} \\
1.74^{\mathrm{b}} \mathrm{b}\end{array}$ & $\begin{array}{l}0.16^{\mathrm{a}} \\
3.84^{\mathrm{b}}\end{array}$ \\
\hline
\end{tabular}

Notes: FEP, MEP, REP and WEP stand for employment in finance, insurance and real estate, manufacturing, retail, and wholesale sectors in Reno MSA, respectively. CG indicates air cargo shipments at Reno-Tahoe International Airport. A dummy variable that takes on value of one for September 11, 2001 is included in the VAR for cointegration tests. $\mathrm{r}$ stands for the number of cointegrating vectors. Critical values are taken from Oterwald-Lenum (1992).

Panel A: No intercepts and no trends in the VAR.

Panel B: Unrestricted intercepts and no trend in the VAR.

The lag number for FEP, REP, and WEP are 13, and 9 for MEP (although several other lag structures were also tested for alternative lags) based on the adjusted LR, logliklihood ratio tests, as well as Akaike and Schwarz criteria. Eigenvalues of the stochastic matrix are computed and available, but not reported.

$*$, **, and $* * *$ represent $10 \%, 5 \%$, and $1 \%$ significance levels, respectively. 
Figure 1. Generalized Impulse Response (s) toOne Standard Error Shock in the Equation for Air Cargo Shipments at RTIA on Manufacturing Employment in Reno MSA

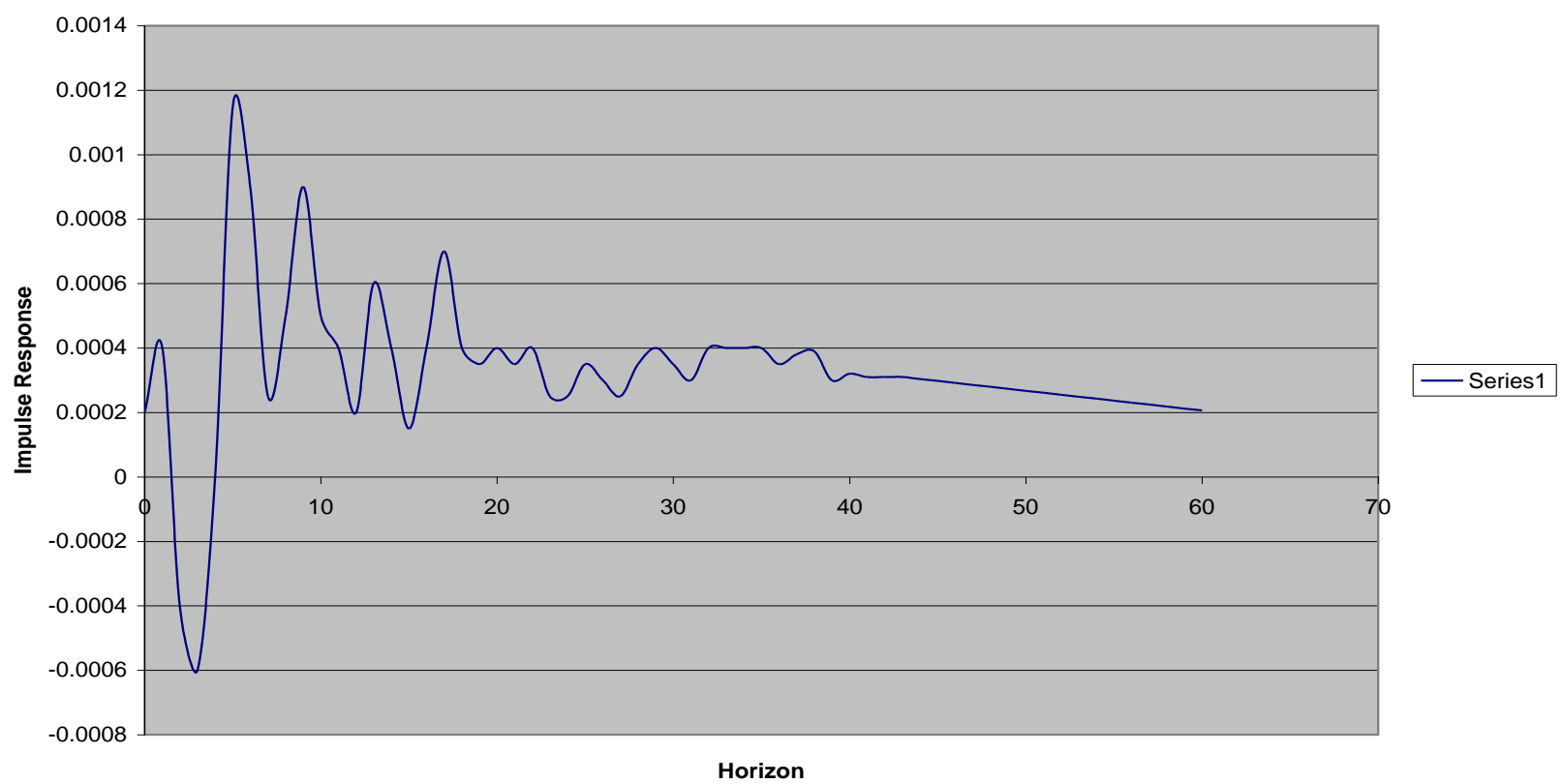

Figure 2. Generlized Impulse Response(s) to one Standard Error Shock in the Equation for Air Cargo Shipments at RTIA on Wholesale Employment in Reno MSA

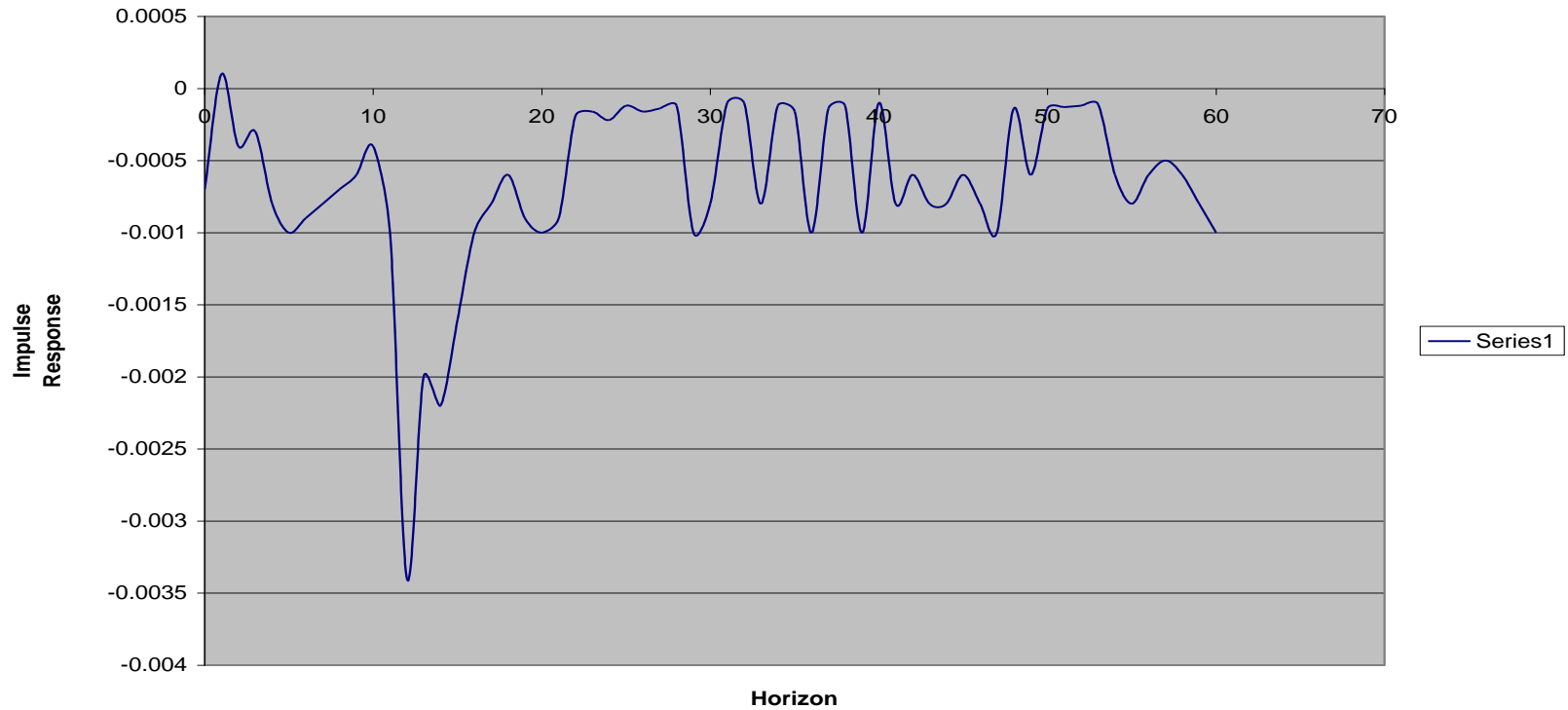




\section{REFERENCES}

1. Adrangi, B., A. Chatrath, A., and K. Raffiee. (2001). The Demand for U.S. Air Transport Service: A Chaos and Nonlinearity Investigation, Transportation Research, 37, 337-353.

2. Akaike, H. (1974). A New Look at Statistical Model Identification, IEEE Transactions on Automatic Ccontrol, 19, 716723.

3. Dickey, D.A. and A. W. Fuller. (1979). Distribution of the Estimators for Autoregressive Time series with a Unit Root, Journal of the American Statistical Association, 1057-1072.

4. Engle, R. F. and C. W. J. Granger. (1987). Co-integration and Error-Correction: Representation, Estimation, and Testing, Econometrical, 315-329.

5. Fair, R.C. and R. J. Schiller. (1990). Comparing Information in Forecasts from Econometric Models, The American Economic Review, 80, 375-389.

6. Funke, M. (1990). Assessing the Forecasting Accuracy of Monthly Vector Autoregressive Models: The Case of five OECD countries, International Journal of Forecasting, 6, 363-378.

7. Hodrick, R. J. and E. C. Prescott (1980). Postwar U.S. Business Cycles: An Empirical Investigation, Discussion Paper 451, Carnegie-Mellon University.

8. Johansen, S. (1988). Statistical Analysis of Cointegration Vectors, Journal of Economic Dynamics and Control, 12, 23154 .

9. Johansen, S. and K. Juselius (1990). Maximum Likelihood Estimation and Inference on Cointegration- With Applications to Demand for Money, Oxford Bulletin of Economics and Statistics, 52, 169-210.

10. Judge, G. G., R.C. Hill, W.E. Griffiths, H. Lutkepohl, and T.C. Lee (1988). Introduction to the Theory and Practice of Econometrics, 2nd edition, John Wiley: New York.

11. Lutkepohl, H. (1985). Comparison of Criteria for Estimating the Order of A Vector Autoregressive Process, Journal of Time Series Analysis, 6, 35-52.

12. MacKinnon, J. G. (1990). Critical Values for Cointegrating Tests, University of California at San Diego, Discussion Paper 90-4.

13. Newey, W. K. and K. West (1987). A Simple Positive-Definite Heteroscedasticity and Autocorrelation Consistent Covariance Matrix, Econometrica, 55, 703-708.

14. Osterwald-Lenum, M. (1992). A Note with Quintiles of the Asymptotic Distribution of the Maximum Likelihood Cointegration Rank Test Statistics. Oxford Bulletin of Economics and Statistics, 54, pp. 461-471.

15. Palm, F. (1983). Structural Econometric Modeling and Time Series Analysis, in Arnold Zellner, Applied Time Series Analysis of Economic Data, Economic Research Report ER-5, US Department of Commerce, Washington, DC.

16. Perron, P. ( 1988). Trends and Random Walks in Macroeconomic Time Series, Journal of Economic Dynamics and Control, 12, 297-332.

17. Phillips, P.C.B. and P. Perron (1988). Testing for a Unit Root in Time Series Regression, Biometrika, 75, 335-346.

18. Radnotti, G. Profit Strategies for Air Transportation. McGraw-Hill Companies, 2002.

19. Ryan, P., K. Raffiee, and D. Bartholet. (June 2002), Northern Nevada Air Cargo Study: Phase I Interviews, Bureau of Business and Economic Research, College of Business Administration, University of Nevada, Reno.

20. Ryan, P., K. Raffiee, and D. Bartholet. (March 2003), Northern Nevada Air Cargo Study: Phase II, Bureau of Business and Economic Research, College of Business Administration, University of Nevada, Reno.

21. World Air Cargo Daily, various publications.

22. Zhang, A. (2003). Analysis of an International Air-Cargo Hub: The Case of Hong Kong, Journal of Air Transport Management, 9, 123-138.

23. Zhang, A., Y. Van Hui and L. Leung. (2004). Air Cargo Alliances and Competition in Passenger Markets, Transportation Research Part E, 40, 83-100.

24. Zhang A. and Y. Zhang (2002). A Model of Air Cargo Liberalization: Passenger vs. All-Cargo Carriers, Transportation Research Part E., 38, 2002, 175-191.

25. Zellner A. (1979). Statistical Analysis of Econometric Models, Journal of the American Statistical Association, 74, 628643.

26. and F. Palm. (1974). Time Series Analysis and Simultaneous Equation Econometric Models, Journal of Econometrics, 2, 17-54. 